\title{
Effect of Soil Probiotic on Water Quality and Soil Quality Maintenance and Growth of Freshwater Fish Pangasius
} hypophthalmus

\author{
Kiran Kumar Bazar 1(i), Naga Jyothi Pemmineti 1,*(i), Subhan Ali Mohammad 2 (D)

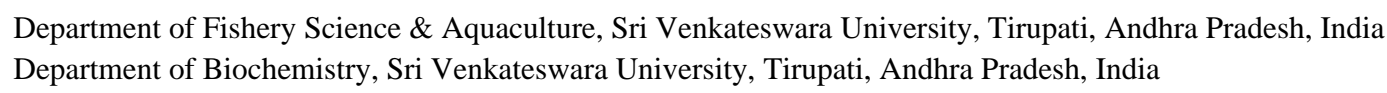

Scopus Author ID 57220522503

Received: 19.04.2021; Revised: 2.06.2021; Accepted: 5.06.2021; Published: 27.06.2021

\begin{abstract}
In recent decades, various procedures have been introduced to improve the conditions of the cultural ponds' conditions in aquaculture. Numerous biological products, including live bacterial inocula, preparation of enzymes, extracts of plant products, and many others, are being promoted to induce water and soil quality conditioners in aquaculture ponds. However, several studies have shown no significant effect of bacterial inoculums, and also the treatment with enzymatic preparation led to an enhancement of microbial mineralization of organic matter, but no effective net production of fish was observed. Probiotics have recently been applied to aquaculture. Probiotics are the live cells or a substrate that induce its benefits by stimulating growth, digestion, and active immune response. Probiotics can also improve water and soil quality. The current study summarizes the role of commercial probiotic 'Super-PS' on water quality and soil quality maintenance during the culture of freshwater fish Pangasius hypophthalmus fingerlings.
\end{abstract}

Keywords: water quality maintenance; growth performance; Pangasius hypophthalmus; probiotic Rhodo bacter and Rhodo coccus species.

(C) 2021 by the authors. This article is an open-access article distributed under the terms and conditions of the Creative Commons Attribution (CC BY) license (https://creativecommons.org/licenses/by/4.0/).

\section{Introduction}

Aquaculture, known as the fastest-growing food-producing sector globally, is heading towards new directions, intensifying and diversifying [1,2]. The industry is now facing many challenges with the increase in the intensification and commercialization of aquaculture production. Pragnya et al., 2020 [3] reported bioaccumulation of heavy metals in different organs of fish Pangasius hypophthalmus, from Visakhapatnam, India, because coastal areas are prone to heavy metal pollution. The challenges majorly include combating diseases, broodstock improvement and domestication, development of appropriate feedstuffs and feeding mechanisms, water quality management, etc., [4]. Among these, disease outbreaks are one of the important problems that affect aquaculture production [5,6]. Probiotics in aquaculture have been widely used as an agent for controlling diseases, enhancing immune response, giving nutritional and enzymatic contributions to the host's digestion, and improving soil and water quality [6]. Probiotics are also regarded as an eco-friendly method in aquaculture. The probiotics may be added to experimental diet feed as live microorganisms to create a balanced indigenous microfloral community in the gastrointestinal tract $[7,8]$. Moreover, probiotics are considered therapeutic agents for usage, and some farmers are already 
using them, preferably over antibiotics [9]. The use of probiotics is increasingly viewed as an alternative source of antibiotic treatment, which controls pathogens through various mechanisms $[10,11]$.

The term probiotic is derived from a Greek word that means "for life" [12]. It was described as a live microbial feed supplement that benefits the host animal by improving its intestinal microbial balance [9]. Fuller 1989 [9] proposed that a good probiotic has the following characteristics:

(1) Effectiveness in the application;

(2) Nonpathogenic and non-toxic;

(3) Existing as viable cells, preferably in large numbers;

(4) Survival and being actively involved in the metabolism of the gut environment and

(5) Being stabilized and remaining viable during long periods of storage and under field conditions.

The differences in the microbial flora within the intestine of the aquatic and terrestrial animals are due to the effect of their surroundings. Probiotic utilization in fish culture has been known to have several modes of action like the competitive exclusion of pathogenic bacteria through the production of inhibitory compounds; improvement of water and soil quality; enhancement of nutrition diet of host species through the production of supplementary digestive enzymes [11]. The effect of commercial soil probiotic 'Super-PS' contains a combination of Rhodobacter and Rhodococcus species used to improve water and soil quality and control bacterial infections. Probiotics Rhodobacter and Rhodococcus species are live preparations of microbial cells that, when ingested in enough concentration, beneficially affect the host's health and growth by improving the intestinal microbial balance [9]. To attain beneficial effects in fishes, probiotics could be added through feed and water. Regular use of probiotics in the feed of fish will be useful to have several health benefits such as efficient digestion of food, effective incorporation of nutrients into body parts, improved growth, elevated immunity, and more survival. The accumulation of organic wastes deteriorates water and soil quality and, in turn, decreases the growth. A supplementation trial was conducted to avoid this problem to determine the effect of commercial soil probiotic 'Super-PS' in the water quality maintenance and growth of Pangasius hypophthalmus culture in a freshwater pond. Probiotic bacteria are known to improve water quality in many ways.

Generally, the Pungus genus refers to a large shark catfish native of freshwater in South and Southeast Asia. These are primarily benthic omnivores that depend on bacteria, detritus, vegetative material, macroalgae, zooplankton, crustaceans and some fishes for their nutrition. Pangasius (Pangasianodon) included Pangasius gigas and Pangasius hypophthalmus and was diagnosed by the absence of mandibular barbells, the absence of teeth in adults and the presence of a single-lobed swim bladder. Pangasius hypophthalmus is commonly known as Iridescent Shark in Sutchi; Catfish in Thailand or Pla Sawai, Patin in Malaysia, Tra or Basa Catfish in Vietnam. It belongs to the family Pangasidae. Pangasius hypophthalmus has been emerging as an economically important species due to their faster growth, year-round production, and high productivity in Southeast Asian aquaculture. It has good market value as a food fish due to its taste and deliciousness with high protein, minerals, and fat content [13].

Catfish Pangasius hypophthalmus is considered one of the most successful aquaculture species due to its relative ease in culture, fast-growing fish, high-market demand, and suitability to local climate conditions [14]. The Commercial aquaculture production of catfish, Pangasius hypophthalmus has increased rapidly in recent years and has contributed 
significantly to food security and economic development. These fishes are well adapted to low oxygen water and can survive on low diet fishmeal. In India, Andhra Pradesh is the leading state with 25,000 ha under Pangasius hypophthalmus culture in the freshwater sector. The culture of Pangasius hypophthalmus can be considered a unique aquatic farming system in many ways. Production is the fastest growth recorded in any aquaculture sector ever, based on a single species, superseding the production per unit for any form of primary production. Pangasius hypophthalmus fish protein hydrolysate (FPH) with antioxidative, antihypertensive, antimicrobial, and immunomodulatory properties could be used for pharmaceutical, health food well as food processing and preservation industries [15].

Indian farmers are also enthusiastically culturing Pangasius hypophthalmus using improved cultural methods and improvised supplementary feeds, which are commercially available in the market. Because of its relative growth rate (almost one $\mathrm{kg}$ in 90 days), this fish is cultured in many states of India, particularly in Andhra Pradesh, West Bengal, Kerala, and Orissa. The Pangas catfish Pangasius hypophthalmus was first introduced into India in the year 1997 in the state of West Bengal from Bangladesh. Initially, its farming was carried in a limited area in the state of West Bengal; later on, this was cultured on a large scale in the state of Andhra Pradesh. Since 2004, its farming has increased due to commercial importance. Striped catfish (Pangasius hypophthalmus) is a high-fat fish compared to other freshwater fish like snakehead fish and carp. Striped catfish oil contains unsaturated and polyunsaturated fatty acids that are beneficial for health [16].

The culture of Pangasianodon catfish is largely restricted to pond aquaculture systems in India. Information from existing farmers reveals that this fish is cultivated both under monoculture and polyculture with Indian major carps and Chinese carps. However, a monoculture of Pangasius hypophthalmus fetches better performance and profit to farmers. Andhra Pradesh is the major producing state for Pangasius hypophthalmus where most of the farms are located in Krishna and West Godavari districts of Andhra Pradesh. However, concern has arisen about long-term sustainability due to diseases and their negative impacts on socioeconomic aspects and biodiversity. The unregulated culture of Pangasius hypophthalmus has been causing concern to environmental safety and warranting a very cautious food.

\section{Materials and Methods}

\subsection{Source of fish and acclimatization.}

Fingerlings of Pangasius hypophthalmus (Figure 1) collected from government fish farm at Tirupati, Chittoor district, Andhra Pradesh, were brought and acclimatized to the laboratory conditions. Fingerlings of fish were collected from the local fisheries department as per the standard pisciculture procedures and were kept in cement tanks for a week with sufficient aeration and dechlorinated water to acclimatize them to laboratory conditions.

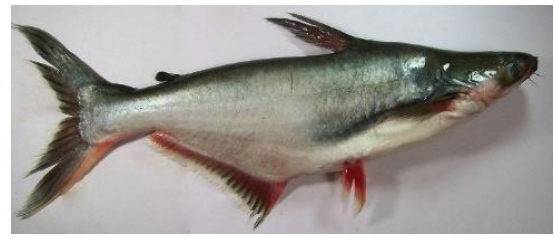

Figure 1. Pangasius hypophthalmus. 


\subsection{Probiotic.}

This study used commercially available probiotic 'Super PS' manufactured by symbiosis animal feeds, A.D.B road, Peddapuram, East Godavari district, Andhra Pradesh, India. Super PS is a soil probiotic made with beneficial bacteria used to improve pond bottom condition, reduce harmful bacteria, and keep the environment friendly for aquaculture. It is composed mainly of Rhodobacter species and Rhodococcus species in $10^{9} \mathrm{CFU} \mathrm{mL}^{-1}$.

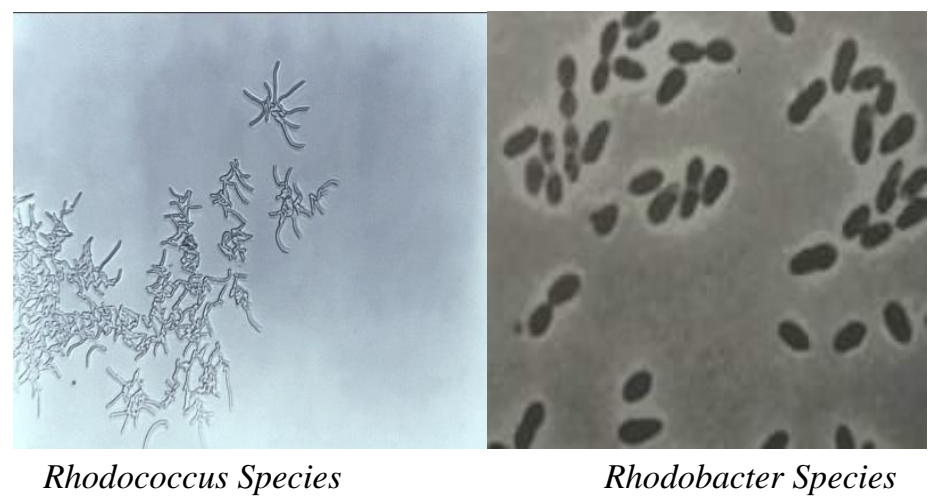

Figure 2. Super PS - Soil Probiotic.

\subsection{Pond preparation and stocking.}

The experiment was carried out in one control and two experimental ponds. All the experimental ponds were dewatered and dried for fifteen days before stocking. The purpose of the sundried pond is to disinfect the pond and stabilize $\mathrm{pH}$; limiting the pond with $\mathrm{CaO}$ was applied at the rate of $125 \mathrm{~kg} / \mathrm{ha}$ with the dusting method [17]. Precautionary measures were taken to avoid any unimportant material in the pond. After removing the sediment, 50 to 100 ltr/ha of Super PS may be sprayed over the soil to utilize the organic matter and establish a beneficial bacterial community. After two weeks of pre-stocking, the ponds are watered up to 1.5 to $2.0 \mathrm{~m}$, and this water level was maintained throughout the experimental period.

After two weeks of pre-stocking and manuring the pond, each pond was stocked with Pangas (Pangasius hypophthalmus). This study is a monoculture that includes only Pangus. The length and average body weight of fishes were noted at the time of stocking. At the time of stocking, fingerlings' size (length of the fish) was measured by centimeter-scale, and the weight of the fish was measured by electronic balance.

\subsection{Experimental design and feeding.}

The experiment was conducted in three ponds. One is kept as a control pond, and the other two are kept as experimental ponds. Initially, the three ponds were dewatered and allowed to dry in sunlight for a month to increase the hydrogen sulfide capacity and remove unnecessary weeds. The edges of the pond are repaired and constructed. After testing soil $\mathrm{pH}$, liming was done at a dose of $250 \mathrm{~kg} / \mathrm{ha}\left(\mathrm{CaCO}_{3}\right)$ that helps to maintain good water quality. All three ponds are maintained with the same volume of water. All three ponds were fenced with fine-meshed nylon net so that any unwanted organisms could not enter the pond from outside. The control pond was cultured without any probiotic treatment and was expressed as $\mathrm{T}_{1}$, and the other two ponds were cultured following a control diet and were expressed as $\mathrm{T}_{2}$ and $\mathrm{T}_{3}$. Initially, the probiotic was supplemented to the experimental ponds by spreading 40 liters Super PS/ha before stocking fishes to utilize the pond bottom's organic matter and to increase the beneficial 
bacteria on the pond bottom. Two supplementary diets were compared for the growth study we prepared for treatment 2 and 3 ponds ( $\mathrm{T}_{2}$ - Experimental diet-1; $\mathrm{T}_{3}$ - Experimental diet-2).

- Diet 1: Control diet $\left(\mathrm{T}_{1}\right)$ was prepared by using the following ingredients (Rice bran $(60 \mathrm{~g})+$ Groundnut oil cake $(100 \mathrm{~g})+$ Soybean cake $(100 \mathrm{~g})+$ Fish meal $(40 \mathrm{~g})$.

- Diet 2: Experimental diet-1 $\left(\mathrm{T}_{2}\right)$ is prepared by using the following ingredients, (Control diet $(10 \mathrm{~g})+$ Soil probiotic "Super PS" $(2 \mathrm{~g})+$ Vitamin C (2g).

- Diet 3: Experimental diet-2 $\left(\mathrm{T}_{3}\right)$ is prepared by using the following ingredients, (Control diet $(10 \mathrm{~g})+$ Soil probiotic "Super PS" $(2 \mathrm{~g})+$ Groundnut oil cake $(3 \mathrm{~g})+$ Vitamin C (2g)

- Experimental duration: 60 days

- Fish size: Fingerlings (6g)

- No. of Replicates: 6 No's

- Number of fish in each replicate: 10 No's.

The fish meal ingredients include Fish oil, Soya meal, Rice bran, Rapeseed meal, Broken Rice, Vitamins, and Minerals. The average body weight was recorded at the time of stocking. After stocking of fish, Super PS's dose was $0.5 \mathrm{ppm} /$ week at the starting stage, 1 $\mathrm{ppm} /$ week at the middle stage, and 1-2 ppm/week at the last stage of the experiment. This probiotic is given to fish through the feed.

\subsection{Water quality parameters.}

In the present study, physicochemical parameters of water and probiotic bacterial loads were studied at fortnight intervals by collecting water samples between 8 and 10 a.m. The physicochemical parameters were measured by the standard methods and field instruments. Water temperature was measured in the pond itself by using a standard centigrade thermometer. Field test instruments were used to examine water $\mathrm{pH}$ (Digital mini - $\mathrm{pH}$ meter, model 55) and dissolved oxygen (YSI-58). Transparency of water was measured in terms of light penetration method using Secchi disc [18]. Salinity was measured with a refractometer (Japan). Total ammonia [19], Nitrate - Nitrogen [20], and total alkalinity \& Hardness [19] were analyzed by the standard protocols following the methods suggested by Golterman and Clymo (1970) [21]; Wetzel and Likens (1979) [22]; APHA (1999) [23]. Total ammonia concentration was measured by Hach comparison apparatus following the method reported by APHA, (1989) [19], and the Deionized ammonia $\left(\mathrm{NH}_{3}\right)$ was calculated from total ammonia according to Boyd (1990) [18]. Nitrate-nitrogen was measured by phenolsulphonic acid method, according to Boyd (1984) [20]. Colour readings were measured with the spectrophotometer (Milton Roy $21 \mathrm{D}$ model) at $410 \mathrm{~nm}$ wavelength. Total alkalinity and total hardness were measured by titration, according to APHA (1985) [24].

\subsection{Soil quality parameters.}

Soil $\mathrm{pH}$ was determined electrochemically using an electrode $\mathrm{pH}$ meter Jackson (1973) [25], and the ratio of soil to water was 1:25. The electrical conductivity of soil was measured with the help of EC meter. Walkley and Black's wet oxidation method was used to determining the Organic Carbon within the samples. The levels of $\mathrm{Ca}$ and $\mathrm{Mg}$ were determined $\mathrm{NH}_{4} \mathrm{OAc}$. (pH-7.0) extract by the titrimetric method as described by Jackson [25]. 


\subsection{Bacterial analysis.}

Two fish as an initial sample before the commencement of the experiment and two fish from each trough at the termination of the experiment were starved for 24 hours in order to clean their intestinal tract before being sacrificed. The gut was aseptically dissected out both prior to commencement and at the termination of the experiment. Then the gut was homogenized with sterilized and chilled 0.1M, PBS, pH 7.4 (10:1 volume: weight). After five serial 1:10 dilutions, the homogenate was plated on a pseudomonas base medium (Hi-medium Mumbai). $0.1 \mathrm{~mL}$ of the sample was inoculated into the medium and incubated at 370C for 24 to 48 hours from the diluents. All the determinations were carried out in triplicates following incubation; plates containing viable colonies were used to calculate bacterial population results. The bacterial load of the fish gut was expressed as a number of colonies forming units per ' $\mathrm{g}$ ' gut tissue CFU/g [26].

\subsection{Growth performance analysis.}

Growth performance was studied by different growth parameters. Average daily growth (ADG), Specific growth rate (SGR), Feed conversion ratio (FCR), and protein efficiency ratio (PER) was calculated and statistically analyzed (ANOVA). Final weight gain\%, Survival rate (SR) \%, total feed consumption, and total yield $(\mathrm{Kg})$ were estimated. The following growth parameters were used for studying the growth performance of Pangas [26].

Average daily gain $(\mathrm{g})=$ Final weight $(\mathrm{g}) /$ Duration of culture (days)

Final Weight Gain \% = Final Weight $(\mathrm{g})-$ Initial Weight $(\mathrm{g}) /$ Initial Weight $(\mathrm{g}) \times 100$

Survival rate $\%=$ No of fish harvested $/$ No of fish stocked $\times 100$

Feed Conversion Ratio = Dry weight of feed consumed/ Increase in wet weight of fish;

Protein Efficiency Ratio = Wet weight gain of fish/ Protein consumed and

Specific Growth Rate $=[($ In final weight - In initial weight $) /$ days on trial $] \times 100$

\subsection{Statistical analysis.}

Statistical analysis was done by one-way analysis of variance (ANOVA) using MSEXCEL and SPSS 16.0 software. The mean difference between different treatments was tested for significance at $\mathrm{P}<0.05$, and Duncan's multiple range tests made comparisons to find out a significant difference between different treatments in respect of growth.

\section{Results and Discussion}

\subsection{Water quality parameters.}

In the present study, important water quality parameters, like $\mathrm{pH}$, temperature, dissolved oxygen (DO), alkalinity, hardness, ammonia, nitrite, salinity were studied, and their values of Mean \pm S.D $(n=6)$ and ranges during the supplementation of a control diet and supplementary diets were shown in Table 1 . All the water quality parameters were within the acceptable range for the freshwater culture of fish. In the present study, water quality parameters of the ponds treated with probiotics were observed to have a good impact, which might be because of the microbes' various roles. Thus, probiotics were useful in maintaining the pond water $\mathrm{pH}$ at the desired level [27]. The dissolved oxygen levels were maintained optimum in the ponds treated with an experimental diet. This may be due to the effect of probiotics, which are favored in the mineralization of organic matter. The nutrients, nitrate-N, 
nitrite- $\mathrm{N}$, and ammonia- $\mathrm{N}$ in the pond water, did not follow the same distribution pattern, and the variations may be due to biological or chemical reactions or a combination of these two. The concentrations of ammonia and nitrites in control-treated pond $\mathrm{T}_{1}$ were slightly higher than that of the experimental treated ponds $\mathrm{T}_{2}$ and $\mathrm{T}_{3}$ (Table 1).

\subsection{Soil quality parameters.}

In the present study, various soil quality parameters $(\mathrm{pH}$, organic carbon, electrical conductivity, phosphorus, calcium, magnesium) were measured and found to be within the culturable range presented in Table 2 . The soil $\mathrm{pH}$ was more or less the same throughout the study period in both control and probiotic treated ponds. The $\mathrm{pH}$ of $6.8-7.6$ range was observed. The electrical conductivity was 9 observed more in a probiotic treated pond in comparison to the control pond compared. Current study data shows that the standard concentrations of total phosphorus increased in the probiotic treated pond compared to the control pond $(2.57 \%-3.1 \%)$. The Total Organic Carbon showed a significant difference between the control and probiotic treated pond $(1.055 \%-1.35 \%)(\mathrm{P}<0.05)$. Correspondingly the $\mathrm{Ca}$ and $\mathrm{Mg}$ levels also showed significant sediment changes after treated to commercial soil probiotic 'Super PS'.

\subsection{Bacterial analysis.}

Soil probiotic 'Super PS' contain Rhodobacter species and Rhodococcus species were added to the water of the ponds supplemented with experimental diet 1 and diet 2, whereas no probiotic was added to control ponds.
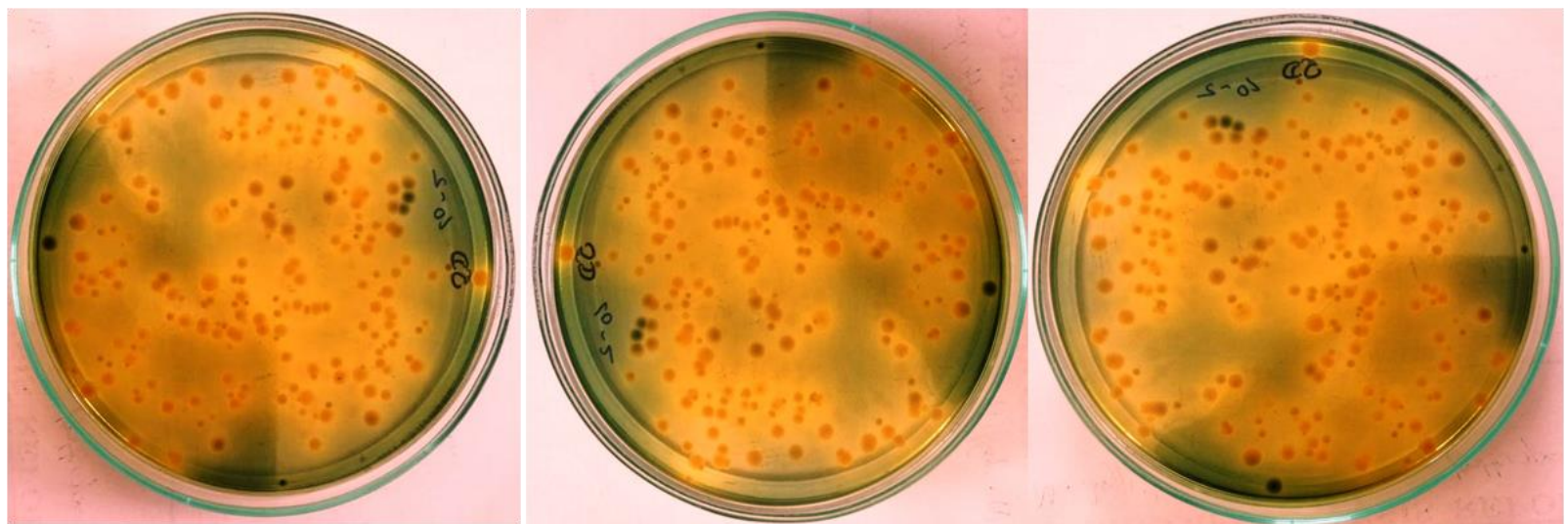

Figure 3. The relative bacterial loads during the culture period in different Petri plates.

Table 1. Water quality parameters in control ponds and probiotic treated ponds that contain Pangasius hypophthalmus fingerlings.

\begin{tabular}{|c|c|c|c|c|c|c|}
\hline \multirow{2}{*}{$\begin{array}{l}\text { Physico-Chemical } \\
\text { parameters }\end{array}$} & \multicolumn{2}{|c|}{ Feed 1: Control diet } & \multicolumn{2}{|c|}{ Feed 2: Experimental diet-1 } & \multicolumn{2}{|c|}{ Feed 3: Experimental diet-2 } \\
\hline & Mean \pm S.D & Range & Mean \pm S.D & Range & Mean \pm S.D & Range \\
\hline Water temperature $\left({ }^{0} \mathrm{C}\right)$ & $27.41 \pm 4.51$ & $25.3-30.2$ & $27.41 \pm 4.54$ & $25.1-31.50$ & $27.41 \pm 4.36$ & $25.60-31.50$ \\
\hline $\begin{array}{l}\text { Secchi disc transparency } \\
(\mathrm{cm})\end{array}$ & $35.15 \pm 5.30$ & $28.0-44.0$ & $33.11 \pm 3.25$ & $28.02-40.0$ & $32.06 \pm 3.20$ & $28.50-39.20$ \\
\hline Dissolved Oxygen $(\mathrm{mg} / \mathrm{mL})$ & $5.10 \pm 0.67$ & $4.6-6.0$ & $5.21 \pm 0.56$ & $4.1-6.2$ & $5.32 \pm 0.53$ & $4.3-6.2$ \\
\hline $\mathrm{pH}$ & $7.69 \pm 0.19$ & $7.0-8.4$ & $7.76 \pm 0.25$ & $7.0-8.2$ & $7.79 \pm 0.31$ & $7.0-8.5$ \\
\hline $\begin{array}{l}\text { Total alkalinity }(\mathrm{mg} / \mathrm{L} \text { as } \\
\left.\mathrm{CaCO}_{3}\right)\end{array}$ & $125.20 \pm 16.6$ & $110-152$ & $123.57 \pm 10.01$ & $120-180$ & $143 \pm 16.75$ & $120-184$ \\
\hline $\begin{array}{l}\text { Total hardness (mg/L as } \\
\left.\mathrm{CaCO}_{3}\right)\end{array}$ & $215.3 \pm 46.8$ & $150-270$ & $250.4 \pm 52.8$ & $190-305$ & $262.8 \pm 44.2$ & $205-310$ \\
\hline Nitrite-N (mg/L) & $0.25 \pm 0.1$ & $0.10-0.30$ & $0.06 \pm 0.02$ & $0.04 \pm 0.08$ & $0.06 \pm 0.02$ & $0.04-0.08$ \\
\hline Nitrate-N (mg/L) & $0.21 \pm 0.07$ & $0.10-0.3$ & $0.31 \pm 0.10$ & $0.12-0.47$ & $0.47 \pm 0.05$ & $0.40-0.41$ \\
\hline Ammonia-N (mg/L) & $1.05 \pm 0.11$ & $0.90-1.25$ & $0.28 \pm 0.03$ & $0.25-0.32$ & $0.18 \pm 0.02$ & $0.16-0.25$ \\
\hline
\end{tabular}


Heterotrophic bacterial count (CFU/g gut tissue) in Pangasius hypophthalmus fingerlings fed with a control diet and experimental diets were shown in Table 3 . The total heterotrophic bacteria (THB) were high in experimental diets received fingerlings compared with control. The loads recorded were $3.76 \times 10^{3} \mathrm{cfu} / \mathrm{mL}$ in experimental diet $1 ; 4.20 \times 10^{3}$ $\mathrm{cfu} / \mathrm{mL}$ in diet 2 , and $1.01 \times 10^{3} \mathrm{cfu} / \mathrm{mL}$ in control diet received fingerlings. The relative bacterial loads during the culture period in different Petri plates were shown in Figures 2 and 3. The differences in growth and survival of several bacterial colonies from the gut of fingerlings Pangasius hypophthalmus between control and treated groups could be attributed to the quality of diets.

Table 2. Soil quality parameters in control ponds and probiotic treated ponds that contain Pangasius hypophthalmus fingerlings.

\begin{tabular}{l|l|l|l}
$\begin{array}{l}\text { Physico-chemical } \\
\text { parameters }\end{array}$ & Feed 1: Control diet & Feed 2: Experimental diet-1 & Feed 3: Experimental diet-2 \\
\hline $\mathrm{pH}($ ranges $)$ & $6.6-7.5^{\mathrm{a}}$ & $6.8-7.7^{\mathrm{b}}$ & $7.1-7.8^{\mathrm{c}}$ \\
\hline $\begin{array}{l}\text { Electrical Conductivity } \\
(\mathrm{ds} / \mathrm{m})(\text { ranges })\end{array}$ & $2.2-6.94^{\mathrm{a}}$ & $5.6-6.25^{\mathrm{b}}$ & $5.7-6.91^{\mathrm{c}}$ \\
\hline $\mathrm{P}(\mathrm{meq} / 100 \mathrm{gm})(\%)$ & $2.65^{\mathrm{a}}$ & $3.0^{\mathrm{b}}$ & $3.2^{\mathrm{b}}$ \\
\hline Organic Carbon $(\%)$ & $1.1355^{\mathrm{a}}$ & $1.1475^{\mathrm{b}}$ & $1.1492^{\mathrm{c}}$ \\
\hline $\mathrm{Ca}($ ranges $)(\%)$ & $0.13-0.15^{\mathrm{a}}$ & $0.14-0.19^{\mathrm{b}}$ & $0.15-0.20^{\mathrm{b}}$ \\
\hline $\begin{array}{l}\text { Mg (ranges) }(\%) \\
\text { Data are Mean values } \pm \text { S.D }(\mathrm{n}=3) \text { Values in the same row with the same superscripts are not significantly different } \\
(\mathrm{P}<0.05)(\mathrm{DMRT}) .\end{array}$
\end{tabular}

Table 3. Heterotrophic bacterial count (CFU/g gut tissue) in Pangasius hypophthalmus fingerlings fed with control and experimental diets for 60 days.

\begin{tabular}{l|l|l|l}
${ }^{\mathrm{a}} \mathbf{C F U} / \mathrm{g}$ gut & Control diet & Experimental diet 1 & Experimental diet 2 \\
\hline $\begin{array}{l}\text { Bacterial count on pseudomonas base } \\
\text { medium (PBM) }\end{array}$ & $1.01 \times 10^{3 \mathrm{a}} \mathrm{cfu} / \mathrm{mL}$ & $3.76 \times 10^{3 \mathrm{~b}} \mathrm{cfu} / \mathrm{mL}$ & $4.20 \times 10^{3 \mathrm{c}} \mathrm{cfu} / \mathrm{mL}$
\end{tabular}

Data are Mean values \pm S.D ( $=3$ ) Values in the same row with the same superscripts are not significantly different $(\mathrm{P}<0.05)(\mathrm{DMRT})$.

\subsection{Growth performance.}

The data regarding growth performance and feed utilization by Pangasius hypophthalmus fingerlings fed experimental diets were presented in Table 4. There were significant differences in the final average weight of Pangasius hypophthalmus fingerlings among all the ponds $(\mathrm{P}<0.05)$. Dietary supplementation of 'Super PS' probiotic showed significant growth performance and feed utilization efficiencies over the control diet-fed fingerlings. After completion of 60 days of the culture period, the final average weight gain $(\%)$ was highest for the experimental diet 2 fingerlings, which differed significantly $(\mathrm{P}<0.05)$ from that of experimental diet 1 and control. During the culture period, the highest weight gain was found in the pond fed with experimental diets. The soil probiotic Super PS was used. The lowest weight gain was found in the control pond. SGR showed a similar trend. The probiotic treated pond showed better SGR than the control ponds, which was significantly different $(\mathrm{P}<0.05)$. FCR and PER were best for the experimental diet 2 fish group, which showed a significant difference $(\mathrm{P}<0.05)$ than that of experimental diet 1 and control. At the end of the experiment, the survival rate of fingerlings was highest in the ponds treated with experimental diets, whereas it was low in the control ponds. A however less significant difference was found among the experimental diet treated ponds $\mathrm{T}_{2}$ and $\mathrm{T}_{3}(\mathrm{P}<0.05)$. 
Table 4. Growth and feed utilization efficiency in Pangasius hypophthalmus fingerlings fed with control and experimental diets for 60 days.

\begin{tabular}{|c|c|c|c|}
\hline Parameter & Control diet & Experimental diet 1 & Experimental diet 2 \\
\hline Initial average weight & $9.85 \pm 0.01^{\mathrm{a}}$ & $9.85 \pm 0.02^{\mathrm{a}}$ & $9.85 \pm 0.01^{\mathrm{a}}$ \\
\hline Final average weight & $81.63 \pm 7.84^{\mathrm{a}}$ & $140.12 \pm 4.91^{\mathrm{b}}$ & $156.55 \pm 6.83^{c}$ \\
\hline Weight gain $(\%)$ & $728.40 \pm 0.02^{\mathrm{a}}$ & $1332.53 \pm 0.02^{\mathrm{b}}$ & $1489.34 \pm 0.02^{\mathrm{c}}$ \\
\hline Survival (\%) & $78.2^{\mathrm{a}}$ & $89.67 \pm 1.15^{\mathrm{b}}$ & $91.67 \pm 1.15^{\mathrm{c}}$ \\
\hline $\begin{array}{l}\text { Food intake ( } \mathrm{g} / \mathrm{kg} \text { body } \\
\text { weight of fish/day) }\end{array}$ & $10.03 \pm 0.11^{\mathrm{a}}$ & $10.04 \pm 0.02^{\mathrm{a}}$ & $10.06 \pm 0.15^{\mathrm{a}}$ \\
\hline FCR & $2.41 \pm 0.06^{\mathrm{a}}$ & $2.21 \pm 0.03^{\mathrm{ab}}$ & $2.07 \pm 0.02^{\mathrm{b}}$ \\
\hline PER & $1.02 \pm 0.01^{\mathrm{a}}$ & $1.36 \pm 0.02^{\mathrm{b}}$ & $1.59 \pm 0.01^{\mathrm{c}}$ \\
\hline SGR $\left(\%\right.$ day $\left.^{-1}\right)$ & $2.45 \pm 0.02^{\mathrm{a}}$ & $2.61 \pm 0.012^{\mathrm{ab}}$ & $2.70 \pm 0.012^{b}$ \\
\hline
\end{tabular}

\subsection{Discussion and conclusion.}

In fish culture systems, several commercial antibiotics are used for disease management in order to increase productivity. Though these are advisable methods that cause environmental hazards, the same chemicals are being used for excess productivity. To reduce these hazards and develop antibiotic-resistant culture, probiotics have been developed [28]. Probiotics reduce the diseases caused by pathogens and make the fish more resistant [29,30]. Probiotics sometimes show a direct growth-promoting effect on fish either by a live involvement in nutrients uptake or by providing nutrients or vitamins to the host [31]. It has also been experimentally shown that Probiotics indeed enhance fish growth [32-35]. Oscar et al., 2019 [36] reported for the first time that the normal concentrations of Ig M like antibody in striped catfish Pangasius hypophthalmus grown in recirculating aquaculture systems. The current study aims to find out the effect of soil probiotics on water, the soil quality of the pond in which they are cultured, and the enhancement in the growth parameters and microbial analysis in the gut of Pangasius hypophthalmus by using dietary Probiotics. The quality of water for fish ponds depends upon the nature of the soil, water source, and the location of ponds [37]. The quality of water is determined by various parameters of the water [38]. Consequently, the sector has developed strategies in various countries to improve water quality and fish growth.

In the present study, a commercial soil probiotic, 'Super PS' was used as a feed supplement. 'Super PS' is a soil probiotics made with beneficial bacteria, which is used to improve pond bottom conditions, reduces harmful bacteria, and keep the environment friendly for aquaculture. It is composed mainly of Rhodobacter species Pangasius and Rhodococcus species. Pangasius Rhodococcus is a genus of aerobic, non-sporulating, non-motile Grampositive bacteria and has thrived in a broad range of environments, including soil, water, and eukaryotic cells. A major application of Rhodococcus arises from bioconversion, using biological systems to convert cheap starting material into more valuable compounds, Rhodobacter, a genus of gram-negative bacteria widely distributed in freshwater as well as marine and hypersaline habitats. Species Rhodobacter has a wide range of metabolic capabilities, including photosynthesis, lithotrophs, and aerobic and anaerobic respiration. It can also fix nitrogen. These capabilities allow it to survive in a number of varied habitats. The current study showed soil probiotic super PS had enhanced the production of experimental ponds compared to control ponds. Application of Probiotics to the ponds was found to improve the water quality parameters and also the sediment condition in the pond bottom, thereby enabling the successful culture and harvest. Further, Probiotics are nonpathogenic and nontoxic organisms without undesirable side effects when administered to aquatic organisms [39]. 
Probiotics are bioresponsive or eco-friendly agents. They can be introduced into the culture environment to control and compete with pathogenic bacteria and also to promote the growth of culture organisms. Several studies have accredited the effect of probiotics on the competition for energy sources [35], [39-44].

In the present experiments with soil, Probiotics supplemented ponds gave a better production, and water parameters such as $\mathrm{pH}$ also are maintained at optimal range. Thus probiotic was found to use full in maintaining the pond water $\mathrm{pH}$ the desired level [27]. Water quality parameters were much improved in experimental ponds when compared to control ponds. Among all the treatments, $\mathrm{T}_{2}$ goes to better survival and high yield. These results are in agreement with earlier published similar results by Sreenivasulu et al., 2018 [32] and Abasali and Mohmad, 2011 [45]. In the present study, the application of soil Probiotics reduced organic matter loads. In the present study, the application of soil probiotic significantly reduced ammonia levels in experimental ponds than control ponds in which probiotic was not used. Among all the treatments, $\mathrm{T}_{2}$ yielded better results, i.e., in fish weight, survival, and yield also.

The application of probiotics in the fish culture ponds appears to be having more impact. There is an increasingly heavy demand for fish production, and a simultaneous increase in the search for an alternative to antibiotics is also increasing. The application of Probiotics intended for the culture system is now attracting considerable attention. Several commercial products are available nowadays, particularly directed at the culture organisms.

The beneficial microorganisms greatly impacted the pathogenic organisms and improved water quality [46-49]. These bacteria are important to aqua farmers; without them, it is difficult to maintain a healthy environment in aquaculture ponds. Since the beginning of probiotics in aquaculture, a growing number of studies have demonstrated their ability to control potential pathogens and increase the growth rates and welfare of cultured aquatic animals [50-54].

In the present study, the water quality parameters of the ponds were within the culturable range. Water quality parameters of the ponds treated with Probiotics were observed to be good, which might be because of the various roles played by the microbes. During the observation period, the amplitude of variation in water temperature was very narrow (Table 1), which is considered characteristic of tropical waters [55-58]. The water temperature, in general, follows the pattern of fluctuation of air temperature. Transparency of water showed an inverse correlation with temperature and negatively correlated with dissolved oxygen. These relations are interdependent and could be explained by the high temperatures being conducive to the development of phytoplankton. With the increase in the densities of phytoplankton's a corresponding decrease in the Secchi disc transparency and increase in dissolved oxygen content was observed. This might be due to the beneficial effect of Probiotics, which induced mineralization of organic matter. $\mathrm{pH}$ of water has been found to be positively correlated with dissolved oxygen. It is well established that the carbonates increase the $\mathrm{pH}$ of water on hydrolysis. Simultaneously the photosynthetic release of oxygen increases the dissolved oxygen content in the water. The relationship between $\mathrm{pH}$, free carbon dioxide, carbonates, and bicarbonates has been discussed by many workers $[59,60]$.

The total amount of ammonia and nitrite level was reduced in Probiotics treated ponds rather than control, and the lowest level was found in $T_{2}$. This is due to the impact of beneficial bacteria, which used the dissolved organic material as their nutrient and for nitrification rapidly. Thus by maintaining the ammonia level, probiotic helps in maintaining good water quality and thereby keeping the fishes disease-free. Suhendra et al., 1997 [61] found that routine use of 
commercial Probiotics resulted in reduced organic matter accumulation, improved water quality, and enhanced environmental conditions. Current study data showed the standard concentrations of TP (2.65-3.2\%), organic carbon (OC) (1.355-1.1492\%), Ca (0.13-0.20\%), $\mathrm{Mg}(0.07-0.12 \%)$ in the sediment after the ponds are treated with commercial probiotic 'Super PS'.

During the whole culture period in the experiment, all the probiotic-supplemented diets increased final weight. The weight gain infers that the addition of probiotics increased Pangas' growth performance. The average bodyweight of the harvested pangas was $81.63 \pm 7.84 \mathrm{~g}$ $156.55 \pm 6.83 \mathrm{~g}$ in Probiotics treated and controlled ponds, respectively, and the difference was significant between these two productions $(\mathrm{P}<0.05)$. The growth was much better in the probiotic pond than in the control pond. Results showed that all probiotic-supplemented diets resulted in higher growth in pangas than the control diet. This result is very inspiring in fish culture with Probiotics as the size of fish is relatively better. In the present study, the average survival rate was $90.67 \pm 1.15 \%$ in Probiotics ponds and $78.20 \pm 3.0 \%$ in controlled ponds, and the difference was significant between these two productions $(\mathrm{P}<0.05)$. In probiotic supplemented ponds survival rate was $15.38 \%$ more than the control pond.

Simultaneously the conclusion obtained from the present study is that the probiotic plays a vital role in the growth, survival, and disease resistance of the aquatic animal by maintaining good water and soil quality parameters throughout the culture period. Probiotic treatment has become a strong alternative to antibiotics for the fish culture system. The study significantly states that probiotics have shown a significant effect on the growth, survival, and productivity of Pangasius hypophthalmus culture. The combined application of soil probiotic and protein feed probiotics supplement $\mathrm{T}_{2}$ showed the best growth performance, which was significantly higher. The findings from this study could be applied to the farmer's level to increase Pangas' production.

\section{Conclusions}

It can be concluded that the commercial soil probiotic 'Super - PS', which is used as a feed supplement, mainly composed of Rhodobacter and Rhodo coccus species probiotic bacteria, causes a significant increase in water and soil quality parameters along with the growth of freshwater fish Pangasius hypophthalmus.

\section{Funding}

This research received no external funding.

\section{Acknowledgments}

This research has no acknowledgment.

\section{Conflicts of Interest}

The authors declare no conflict of interest.

\section{References}

1. Stentiford, G.D.; Bateman, I.J.; Hinchliffe, S.J.; Bass, D.; Hartnell, R.; Santos, E.M.; Devlin, M.J.; Feist, S.W.; Taylor, N.G.H.; Verner-Jeffreys, D.W.; van Aerle, R.; Peeler, E.J.; Higman, W.A.; Smith, L.; Baines, 
R.; Behringer, D.C.; Katsiadaki, I.; Froehlich, H.E.; Tyler, C.R. Sustainable aquaculture through the One Health lens. Nature Food 2020, 1, 468-474, https://doi.org/10.1038/s43016-020-0127-5.

2. Bondad-Reantaso, M.G.; Subasinghe, R.P.; Arthur, J.R.; Ogawa, K.; Chinabut, S.; Adlard, R.; Tan, Z.; Shariff, M. Disease and health management in Asian aquaculture. Veterinary Parasitology 2005, 132, 249272, https://doi.org/10.1016/j.vetpar.2005.07.005.

3. Pragnya, M.; Dinesh Kumar, S.; Solomon Raju, A.J.; Murthy, L.N. Bioaccumulation of heavy metals in different organs of Labeo rohita, Pangasius hypophthalmus, and Katsuwonus pelamis from Visakhapatnam, India. Marine Pollution Bulletin 2020, 157, https://doi.org/10.1016/j.marpolbul.2020.111326.

4. Subasinghe, R.; Curry, D.; McGladdery S.; Bartley, D. Recent technological innovations in aquaculture. Review of the State of World Aquaculture, FAO Fisheries Circular2003, 59-74.

5. Mzula, A.; Wambura, P.N.; Mdegela, R.H.; Shirima, G.M. Present status of aquaculture and the challenge of bacterial diseases in freshwater farmed fish in Tanzania; A call for sustainable strategies. Aquaculture and Fisheries 2020, https://doi.org/10.1016/j.aaf.2020.05.003.

6. Qi, Z.; Zhang, X.-H.; Boon, N.; Bossier, P. Probiotics in aquaculture of China - Current state, problems and prospect. Aquaculture 2009, 290, 15-21, https://doi.org/10.1016/j.aquaculture.2009.02.012.

7. Hasan, K.N.; Banerjee, G. Recent studies on probiotics as beneficial mediator in aquaculture: a review. The Journal of Basic and Applied Zoology 2020, 81, https://doi.org/10.1186/s41936-020-00190-y.

8. Rengpipat, S.; Rueangruklikhit, T.; Piyatiratitivorakul, S. Evaluations of lactic acid bacteria as probiotics for juvenile seabass Lates calcarifer. Aquaculture Research 2008, 39, 134-143, https://doi.org/10.1111/j.13652109.2007.01864.x.

9. Fuller, R. Probiotics in man and animals. The Journal of Applied Bacteriology1989, 66, 365-78.

10. Silva, D.R.; Sardi, J.d.C.O.; Pitangui, N.d.S.; Roque, S.M.; Silva, A.C.B.d.; Rosalen, P.L. Probiotics as an alternative antimicrobial therapy: Current reality and future directions. Journal of Functional Foods 2020, 73, https://doi.org/10.1016/j.jff.2020.104080.

11. Verschuere, L.; Rombaut, G.; Sorgeloos, P.; Verstraete, W. Probiotic Bacteria as Biological Control Agents in Aquaculture. Microbiology and Molecular Biology Reviews 2000, 64, 655-671, https://doi.org/10.1128/mmbr.64.4.655-671.2000.

12. Gismondo, M.R.; Drago, L.; Lombardi, A. Review of probiotics available to modify gastrointestinal flora. International Journal of Antimicrobial Agents 1999, 12, 287-292,https://doi.org/10.1016/s09248579(99)00050-3.

13. Parven, M.; Alam, M.M.M.; Khalil, S.M.I.; Hamom, A.; Goni, O.; Rahman, M.M.; Abdullah-Al-Mamun, M. Identification of Pathogenic Bacteria from Diseased Thai Pangas Pangasius hypophthalmus with Their Sensitivity to Antibiotics. Microbiology Research Journal international2020, 30, 7-21, https://doi.org/10.9734/MRJI/2020/v30i330201.

14. Baleta, F.N.; Bolaños, J.M. Growth and Immune Response of Pangasius hypophthalmus Fed Diets Containing Seaweed Extracts as immuno stimulant. Brazilian Archives of Biology and Technology 2019, 62, https://doi.org/10.1590/1678-4324-2019180083.

15. Nam, P.V.; Van Hoa, N.; Anh, T.T.L.; Trung, T.S. Towards Zero-waste Recovery of Bioactive Compounds from Catfish (Pangasius hypophthalmus) By-products Using an Enzymatic Method. Waste and Biomass Valorization 2020, 11, 4195-4206,https://doi.org/10.1007/s12649-019-00758-y.

16. Lestari, D.U.; Sumardianto, Lukita, P. The Characteristics of Striped Catfish Oil (Pangasius hypophthalmus) Extracted by Dry Rendering Method at Different Temperatures. Caraka Tani: Journal of Sustainable Agriculture2020, 35, https://doi.org/10.20961/carakatani.v35i1.31604.

17. Wahab, M.A.; Rahman, M.M.; Milstein, A. The effect of common carp, Cyprinus carpio (L.) and mrigal, Cirrhinus mrigala (Hamilton) as bottom feeders in major Indian carp polycultures. Aquaculture Research 2002, 33, 547-556,https://doi.org/10.1046/j.1365-2109.2002.00654.x.

18. Boyd, C.E. Water quality in ponds for aquaculture. Agriculture Experiment Station, Auburn University, Alabama1990, 482.

19. APHA (American Public Health Association, American Water Works Association, and Water Pollution Control Federation). Standard Methods for the Examination of Water and Wastewater. 17th edition. APHA. Washington, DC.1989.

20. Boyd, C.E. Warm water fishponds. Auburn: Alabama Agriculture Experiment Station. Auburn University; Water quality. 1984.

21. Golterman, H.L.; and Clymo, R.S.Methods for chemical analysis of fresh waters. London: International Biological Programme.1970.

22. Wetzel, R.G.; Likens, G.E. Limnological Analyses. Saunders, W.B. Co., Philadelphia. 1979; 357.

23. APHA.Standard methods for the examination of water and wastewater. 21st Ed. Amer Publ. Hlth. Assoc. Inc. New York.1999.

24. APHA.Standard methods for the examination of water and waste water.16th edition. American Public Health Association, New York, Volume 119, 1985; pp. 25-40.

25. Jackson, M.L. Soil Chemical Analysis. Prentice Hall of India Pvt. Ltd., New Delhi, Volume 498.1973.

26. Saha, S.; Hassan, M.A.; Sharma, A. Effect of dietary probiotics supplementation on growth performance of rohu, Labeo rohita fingerlings. International Journal of Pharma and Bio Sciences 2015, 6, B1260-B1268. 
27. Sambasivam, S.; Chandran, R.; Khan, S.A. Role of probiotics on the environment of shrimp pond. Journal of environmental biology 2003, 24, 103-106.

28. Kruse, H.; Sørum, H. Transfer of multiple drug resistance plasmids between bacteria of diverse origins in natural microenvironments. Applied and Environmental Microbiology 1994, 60,4015-21, https://doi.org/10.1128/AEM.60.11.4015-4021.1994.

29. Olsson, J.C.; Westerdahl, A.; Conway, P.L.; Kjelleberg, S. Intestinal colonization potential of turbot (Scophthalmus maximus)- and dab (Limanda limanda)-associated bacteria with inhibitory effects against Vibrio anguillarum. Applied and Environmental Microbiology 1992, 58, 551-6.

30. Tannock, G.W. Control of gastrointestinal pathogens by normal flora. In: Current Perspectives in Microbial Ecology, ed. M.J. Klug \& C.A. Reddy. American Society for Microbiology, Washington, DC, USA, 1984; pp. 374-382.

31. Ringø, E.; Hoseinifar, S.H.; Ghosh, K.; Doan, H.V.; Beck, B.R.; Song, S.K. Lactic Acid Bacteria in FinfishAn Update. Frontiers in Microbiology2018, 9.

32. Sreenivasulu, P.; Naga Jyothi, P.; Subhan Ali, M.D.; Praveenkumar, K. Effect of water probiotic in water quality maintenance and growth of Rohu (Labeo Rohita) Fingerlings. European Journal of Pharmaceutical and Medical Research 2018, 5, 280-286.

33. Noh, S.H.; Han, I.K.; Won, T.H.; Choi, Y.J. Effect of antibiotics, enzyme, yeast culture and probiotics on the growth performance of Israeli carp.Korean Journal of Animal Science (Korea Republic)1994,36, 480486.

34. Bogut, I.; Milakobi, A.; Bukvic, Z.; Zimmer, R. Influence of probiotic (Streptococcus facium, M 74) on growth and content of intestinal microflora in carp (Cyprinus carpio). Journal of Animal Science1998, 43, 231-235..

35. Krishna, P.V.; Prabhavathi, K. Efficacy and suitability of earth worm Megascolex sps as supplementary feed for cat fish Pangasius hypophthalmus in response to different animal protein sources. International Journal of Fisheries and Aquatic Studies2019,7,160-165.

36. Galagarza, O.A.; Smith, S.A.; Mainous, M.E.; Kuhn, D.D. Development of a polyclonal antibody for detection and sensitive quantification of immunoglobulin M-like antibody in Pangasius hypophthalmus plasma. Aquaculture 2019, 513,https://doi.org/10.1016/j.aquaculture.2019.734369.

37. Boyd, C.E.; Romaire, R.P.; Johnston, E. Predicting Early Morning Dissolved Oxygen Concentrations in Channel Catfish Ponds. Transactions of the American Fisheries Society 1978, 107, 484-492.

38. Zakhia, N.; and Cuq, J.L. Traditional methods of fish fermentation in Ghana. Proceedings of the FAO export consultation on fish technology in Africa.ACCRA, Ghana1991, 22-25.

39. Farzanfar, A. The use of probiotics in shrimp aquaculture. FEMS Immunology \& Medical Microbiology 2006, 48, 149-158, https://doi.org/10.1111/j.1574-695X.2006.00116.x.

40. Subhash, S.K.; Lipton, A.P.; Paulraj, R. Influence of probiotic bacterium Lactobacillus acidophilus on the survival and growth of pearl oyster Pinctada fucata spat. Indian Journal of Fisheries 2007, 54, 211-216.

41. Mohideen, M.; Haniffa, M.A. Effect of Probiotic on Microbiological and Haematological Responsiveness of Cat fish (Heteropnuestes fossilis) Challenged with Bacteria Aeromonas hydrophila and Fungi Aphanomyces invadans. Journal of Aquaculture Research and Development2015,6,https://doi.org/10.4172/2155-9546.1000384.

42. Cristea, V.; Patriche, N.; Iulia, G. The Effect On Biochemical Composition of Different Concentrations Probiotic Fed to Juvenile Carp (Cyprinus carpio, L. 1758) In A Recirculating Aquaculture System. Elena Bocioc Scientific Papers Animal Science Series: Lucrări Ştiinţifice - Seria Zootehnie2014,63.

43. Divya, K.R.; Isamma, A.; Arunjith, T.S.; Sureshkumar, S.; and Krishnakumar, V. Effect of Enriched Artemia franciscana on Production, Survival, Growth and Biochemical Composition of the Freshwater Fish Catla catla (Hamilton, 1922).International Journal of Recent Biotechnology 2014,2, 15-24.

44. Janardana Reddy, S. Probiotics in Aquaculture: Importance, Influence and Future Perspectives.International Journal of Bioassays 2015,4, 3710-3718.

45. Abasali, H.; Mohmad, S. Effect of dietary probiotic level on the reproductive performance of female platy Xiphophorus maculates. Journal of Animal and Veterinary Advances 2011, 10, 1209-1213.

46. David I.P.; Tzachi M.S. Chapter 12 - Disease and Biosecurity.In: Sustainable Biofloc Systems for Marine Shrimp.Editor(s): Samocha, T.M. Academic Press, 2019;pp. 219-241, https://doi.org/10.1016/B978-0-12818040-2.00012-5.

47. Prabhu, N.M.; Nazar, A.R.; Rajagopal, S.; Khan, S.A. Use of Probiotics in water quality management during shrimp culture. Journal of Aquaculture in the Tropics1999, 14, 227-236.

48. Shariff, M.; Yusoff, F.; Devaraja, T.N.; Rao, S. The effectiveness of a commercial microbial product in poorly prepared tiger shrimp, Penaeus monodon (Fabricius), ponds. Aquaculture Research 2001, 32, 181187.

49. Irianto, A.; Austin, B. Probiotics in aquaculture. Journal of Fish Diseases 2002, 25, 633-642.

50. Gatesoupe, F.J. The use of probiotics in aquaculture. Aquaculture 1999, 180, 147-165, https://doi.org/10.1016/S0044-8486(99)00187-8.

51. Carnevali, O.; Zamponi, M.C.; Sulpizio, R.; Rollo, A.; Nardi, M.; Orpianesi, C.; Silvi, S.; Caggiano, M.; Polzonetti, A.M.; Cresci, A. Administration of Probiotic Strain to Improve Sea Bream Wellness during 


$\begin{array}{lllll}\text { Development. } & \text { Aquaculture } & \text { International } & \text { 2004, }\end{array}$
https://doi.org/10.1023/B:AQUI.0000042141.85977.bb.

52. Macey, B.M.; Coyne, V.E. Improved growth rate and disease resistance in farmed Haliotis midae through probiotic treatment. Aquaculture https://doi.org/10.1016/J.AQUACULTURE.2004.11.031.

53. Wang, Y.-B.; Xu, Z.-R.; Xia, M.-S. The effectiveness of commercial probiotics in northern white shrimp Penaeus vannamei ponds. Fisheries Science 2005, 71, 1036-1041, https://doi.org/10.1111/j.14442906.2005.01061.x

54. Yanbo, W.; Zirong, X. Effect of probiotics for common carp (Cyprinus carpio) based on growth performance and digestive enzyme activities. Animal Feed Science and Technology 2006, 127, 283-292, https://doi.org/10.1016/j.anifeedsci.2005.09.003.

55. Rahman, M.S.; Chowdhury, M.Y.; Haque, A.K.M.A.; Haq, M.S. Limnological studies of four ponds. Bangladesh Journal of Fisheries1982, 2-5, 25-35.

56. Dewan, D.; Wahab, M.A.; Beveridge, M.C.M.; Rahman, M.H.; and Sarkar, B.K. Food selection, electivity and dietary overlap among planktivorous Chinese and Indian major carp fry and fingerlings grown in extensively managed, rain-fed ponds in Bangladesh. Aquaculture and Fisheries Management1991, 22, 277294.

57. Wahab, M.A.; Aziz, M.E.; Haque, M.M.; Ahmed, Z.F. Effects of frequency of fertilization on water quality and fish yields. Progress. Agric. 1996, 7, 33-39.

58. Ahmed, N.; Demaine, H.; Muir, J. Freshwater prawn farming in Bangladesh: History, present status and future prospects. Aquaculture Research 2008, 39, 806-819.

59. Seenayya, G. Ecological Studies in the Plankton of Certain freshwater Ponds of Hyderabad — India I. Physico-chemical Complexes. Hydrobiologia 1971, 37, 7-31, https://doi.org/10.1007/BF00016365.

60. Rao, C.P. Geochemistry of Early Permian cold-water carbonates (Tasmania, Australia). Chemical Geology 1983, 38, 307-319, https://doi.org/10.1016/0009-2541(83)90061-X.

61. Suhendra, T.; Handoko, J.; Octaviano, D.; Porubcan, R.S.; Douillet, P. Management with bacterial probiotics for Vibrio and virus control in an Indonesian prawn farm. In: Proceedings of the IV Central American Aquaculture Symposium: Sustainable Culture of Shrimp and Tilapia. Alston, D.E.; Green, B.W.; Clifford, H.C. (Eds.), 1997;pp. 201-202. 